\title{
PELAKSANAAN STIMULASI MOTORIK HALUS PADA LATIHAN KEHIDUPAN PRAKTIS DI TK PIONEER MONTESSORI SCHOOL PADANG
}

\author{
Berti Setya Ningsih ${ }^{1}$, Farida Mayar ${ }^{2}$, Delfi Eliza ${ }^{3}$ \\ Fakultas Ilmu Pendidikan \\ Universitas Negeri Padang \\ Email : bertisetyaningsih@gmail.com
}

\begin{abstract}
Abstrak
Penelitian ini bertujuan untuk mendeskripsikan tentang pelaksanaan stimulasi motorik halus pada latihan kehidupan praktis di Taman Kanak-Kanak Pioneer Montessori School Padang. Penelitian ini menggunakan pendekatan kualitatif dengan metode deskriptif. Informan dari penelitian ini adalah kepala sekolah dan guru. Teknik pengumpulan data yang digunakan adalah observasi, wawancara dan dokumentasi. Teknik analisis data dilakukan dengan teknik triangulasi data. Hasil penelitian dari penelitian ini menunjukkan bahwa pelaksanaan stimulasi motorik halus pada latihan kehidupan praktis di Taman Kanak-Kanak Pioneer Montessori School Padang telah dilaksanakan dengan baik. Guru membuat perencanaan sebelum kegiatan memanfaatkan macam-macam kegiatan yang ada pada latihan kehidupan praktis serta menggunakan media dan metode yang menarik. Guru juga melakukan evaluasi pada setiap kegiatan motorik halus.
\end{abstract}

Kata Kunci: Latihan Kehidupan Praktis, Motorik Halus

\begin{abstract}
This study aims to describe the implementation of fine motor stimulation in practical life at the Padang Pioneer Montessori School Kindergarten. This study uses a qualitative approach with descriptive methods. Informants from this study were principals and teachers. Data collection techniques used were observation, interviews and documentation. The data analysis technique is done using data triangulation techniques. The results of this study indicate that the implementation of fine motor stimulation in practical life training at the Padang Pioneer Montessori School Kindergarten has been well implemented. The teacher makes a plan before the activity utilizes the various activities that exist in practical life training and uses interesting media and methods. The teacher also evaluates every fine motor activity.
\end{abstract}

Key Word: Pratical life, fine motor skill

\section{PENDAHULUAN}

Seorang pakar pendidikan anak usia dini Maria Montessori yang berprofesi sebagai seorang dokter berkebangsaan Italia mengungkapkan bahwasanya semua anak usia nol sampai dengan enam tahun berada dalam masa peka. Masa peka adalah suatu masa di mana fungsi-fungsi jiwa menonjolkan diri keluar dan sangat peka terhadap rangsangan dari luar. Anak juga memiliki pikiran yang mudah menyerap (absorbent mind) pada lingkungan sehingga dapat dengan mudah menyerap apapun yang ada disekitarnya. Oleh karena itu, maka semua perkembangan seperti perkembangan bahasa, perkembangan motorik, perkembangan sosial dan 
emosional dituntut untuk berkembang secara optimal.

Selanjutnya Montessori menegaskan bahwa semua anak mempunyai suatu "motivasi bawaan" sejak lahir untuk belajar. Motivasi bawaan tersebut diwujudkan dalam aktivitas gerakan. Perkembangan yang melibatkan gerakan adalah kemampuan motorik. Motorik terbagi atas motorik halus dan motorik kasar. Motorik halus adalah gerakan yang menggunakan otot-otot halus atau sebagian anggota tubuh tertentu, yang dipengaruhi oleh kesempatan untuk belajar dan berlatih, misalnya kemampuan memindahkan benda dari tangan. Montessori dalam pendekatan pembelajarannya memiliki kurikulum yang disebut pratical life atau latihan kehidupan praktis. Dalam pratical life ini memiliki kegiatan yang dapat melatih kemampuan motorik halus anak. Menurut Roopnarine (2011:393) menyatakan bahwa latihan kehidupan praktis merupkan pengalaman praktis di kehidupan sehari-hari yang memiliki tujuan yang mengembangkan keterampilan hidup dan melatih kemandirian yang akan mendukung pembelajaran terfokus. Seperti mendukung perkembangan kemampuan motorik halus anak.

Tujuan dari area latihan kehidupan praktis yang terdapat pada artikel yang ditulisa oleh Batia (2015:604) mengemukakan bahwa area latihan kehidupan praktis mempunyai kegiatan yang bertujuan menstimulasi dan menguatkan ketiga jari dan pergelangan tangan anak.

"The results from this small-scale study indicate that the Montessori Pratical life activities had a significant effect on improving the fine motor skills of kindergartners".

Dalam artikel tersebut dikemukakan bahwa salah satu kurikulum Montessori yaitu Pratical Life Activities atau latihan kehidupan praktis dalam mengembangkan motorik halus di Taman Kanak-kanak. menunjukkan hasil bahwa salah satu kurikulum tersebut memiliki pengaruh yang signifikan terhadap peningkatan keterampilan motorik halus. Sejalan dengan itu, Santrock (2007:216) berpendapat bahwa keterampilan motorik halus adalah keterampilan yang melibatkan gerakan yang diatur secara halus. Menggenggam mainan, mengancingkan baju, atau melakukan apa pun yang memerlukan keterampilan tangan menunjukkan keterampilan motorik halus.

Berdasarkan uraian di atas serta observasi yang telah dilakukan oleh peneliti di Taman Kanak-Kanak Pioneer Montessori School di Kota Padang. Diketahui bahwa sekolah ini menerapkan kurikulum Montessori salah 
satunya ialah pratical life atau latihan kehidupan praktis. Kegiatan yang dikembangkan dalam latihan kehidupan praktis adalah pengembangan motorik halus, maka peneliti tertarik untuk meneliti tentang pelaksanaan stimulasi motorik halus pada latihan kehidupan praktis di Taman Kanak-Kanak Pioneer Montessori School Padang.

\section{METODE}

Penelitian ini menggunakan jenis penelitian deskriptif dengan pendekatan kualitatif. Penelitian ini dilakukan di Taman KanakKanak Pioneer Montessori School Padang, yang beralamat di Jl. Nipah No. 26C, kecamatan Berok Nipah, Padang Barat, Sumatera Barat. Penelitian ini dilaksanakan dari tanggal 10 Oktober 2018 sampai 08 November 2018. Subjek penelitian ini ialah anak kelas toodler dan nursery $I$ Taman Kanak-Kanak Pioneer Montessori school Padang.

\section{Prosedur}

Langkah pertama dalam penelitian ini adalah persiapan instrumen. Instrumen disusun ketika proses pembuatan proposal penelitian, yang berdasarkan kajian teori. Langkah kedua yaitu Wawancara awal yang dilakukan peneliti untuk mengetahui infomasi awal sebelum melakukan penelitian. Selanjutnya Pelaksanaan penelitian, dalam pelaksanaan penelitian, observasi peneliti masuk kedalam kelas tanpa merubah setting pembelajaran, hanya mengamati kegiatan pembelajaran yang sedang dilakukan oleh guru. Kemudian hasil pengamatan dicatat pada lembar observasi. Setelah observasi selesai dilakukan, peneliti akan memasukkan hasil penelitian pada hari tersebut. Setelah semua langkah tersebut peneliti lakukan langkah selanjutnya ialah reduksi data yang diperoleh dari data observasi, wawancara dan dokumentasi maka selanjutnya yaitu mendeskripsikan hasil data.

\section{Teknik Pengumpulan Data dan Instrumen}

Teknik pengumpulan data yang digunakan pada penelitian deskriptif kualitatif adalah observasi, wawancara dan dokumentasi. Berikut akan ditampilkan instrumen yang akan digunakan sebagai data pembanding yaitu:

Tabel 1.Format Observasi Guru dan Anak Pelaksanaan Stimulasi motorik halus pada latihan kehidupan praktis di Taman Kanak-Kanak Pioneer Montessori School Padang

Informan :

Tanggal

\begin{tabular}{|c|c|c|}
\hline No & $\begin{array}{l}\text { Aspek } \\
\text { yang } \\
\text { diamati }\end{array}$ & $\begin{array}{c}\text { Hasil } \\
\text { Pengamatan }\end{array}$ \\
\hline • & $\begin{array}{l}\text { Perencanaa } \\
n \text { stimulasi } \\
\text { motorik } \\
\text { halus pada }\end{array}$ & \begin{tabular}{ll}
\multicolumn{2}{c}{ Perencanaan } \\
stimulasi & motorik \\
halus pada & latihan \\
kehidupan & praktis
\end{tabular} \\
\hline
\end{tabular}




\begin{tabular}{|c|c|}
\hline $\begin{array}{l}\text { latihan } \\
\text { kehidupan } \\
\text { praktis }\end{array}$ & $\begin{array}{l}\text { yang pertama dibuat } \\
\text { oleh guru adalah } \\
\text { individual lesson } \\
\text { plan, lalu dirancang } \\
\text { weekly plan untuk } \\
\text { mingguan selanjutnya } \\
\text { time table untuk } \\
\text { perencanaan harian. }\end{array}$ \\
\hline $\begin{array}{l}\text { a. Guru } \\
\text { membu } \\
\text { at } \\
\text { perenc } \\
\text { anaan } \\
\text { stimula } \\
\text { si } \\
\text { motori } \\
\text { k halus } \\
\text { pada } \\
\text { latihan } \\
\text { kehidu } \\
\text { pan } \\
\text { praktis } \\
\text { Guru } \\
\text { meranc } \\
\text { ang } \\
\text { kegiata } \\
\text { n } \\
\text { berped } \\
\text { oman } \\
\text { pada } \\
\text { tema } \\
\text { dan } \\
\text { sub } \\
\text { tema }\end{array}$ & $\begin{array}{l}\text { a. Guru membuat } \\
\text { perencanaan } \\
\text { kegiatan sebelum } \\
\text { melakukan } \\
\text { stimulasi motorik } \\
\text { halus pada latihan } \\
\text { kehidupan } \\
\text { praktis. Guru } \\
\text { merencanakan } \\
\text { kegiatan, metode } \\
\text { serta media yang } \\
\text { akan diberikan } \\
\text { Guru merancang } \\
\text { kegiatan } \\
\text { berpedoman pada } \\
\text { tema, sub tema } \\
\text { dan kebutuhan } \\
\text { anak. }\end{array}$ \\
\hline $\begin{array}{l}\text { Pelaksanaa } \\
\text { n stimulasi } \\
\text { motorik } \\
\text { halus pada } \\
\text { latihan } \\
\text { kehidupan } \\
\text { praktis }\end{array}$ & \begin{tabular}{l}
\multicolumn{3}{c}{ Pelaksanaan } \\
kegiatan motorik \\
halus pada latihan \\
kehidupan praktis \\
adalah bentuk dari \\
kegiatan sehari-hari \\
anak
\end{tabular} \\
\hline 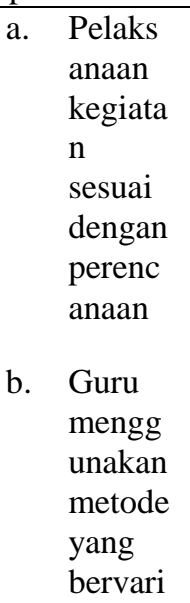 & \begin{tabular}{ll} 
a. & \multicolumn{2}{l}{ Pelaksanaan } \\
kegiatan sebagian \\
sudah sesuai \\
dengan \\
perencanaan \\
b. Pada pelaksanaan \\
stimulasi motorik \\
halus guru \\
menggunakan dua \\
metode yaitu \\
demonstrasi dan \\
pemberian tugas. \\
c. Media yang \\
digunakan guru \\
dalam
\end{tabular} \\
\hline
\end{tabular}

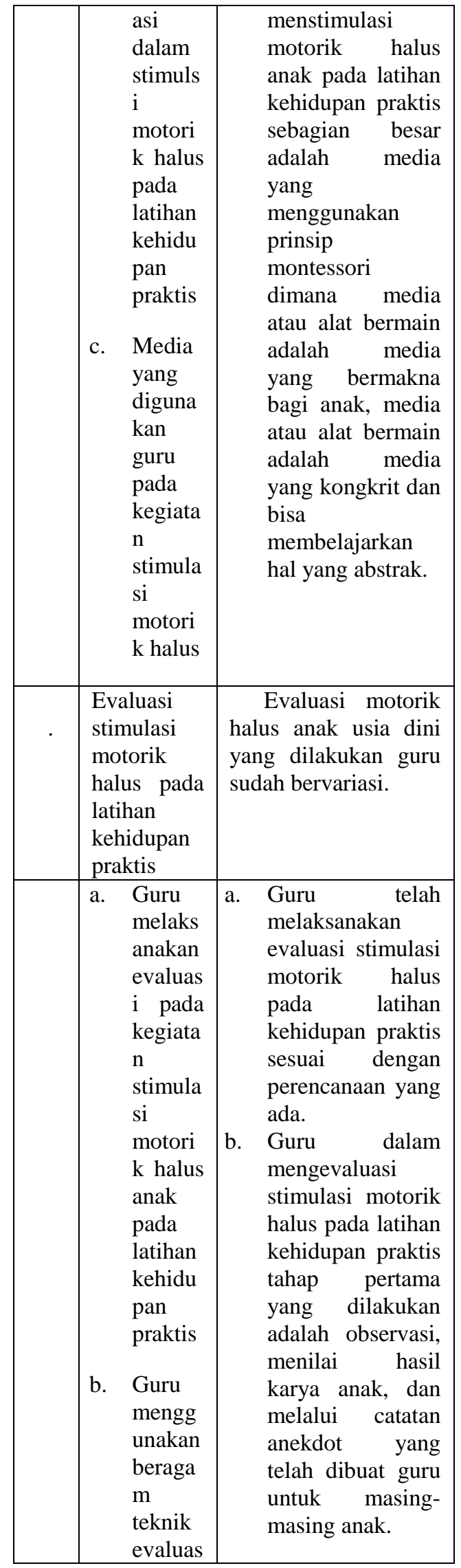




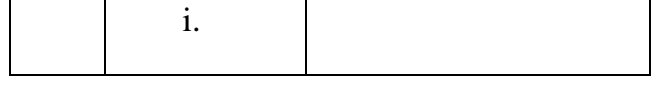

\section{Teknik Analisis Data}

Data dianalis dengan menggunakan teknik model Milles dan Huberman yaitu menggunakan teknik pengumpulan data, reduksi, penyajian data, dan penarikan kesimpulan.

\section{Reduksi Data}

a. Deskripsi Tentang Perencanaan

Stimulasi Motorik Halus Pada

Latihan Kehidupan Praktis

$$
\text { Berdasarkan hasil }
$$

wawancara dengan informan yaitu guru dan kepala sekolah didapatkan perencanaan stimulasi motorik halus pada latihan kehidupan praktis dirancang pada awal semester dalam bentuk lesson plan. Lalu dirancang Weekly plan sebagai pembelajaran yang akan dilaksanakan untuk mingguan. Guru berpedoman pada tema dan perkembangan anak untuk merancang kegiatan. Sedangkan berdasarkan dokumentasi sudah terlihat mengenai perancangan individual lesson plan, weekly plan dan time table untuk anak.

b. Deskripsi Tentang Pelaksanaan Stimulasi Motorik Halus Pada Latihan Kehidupan Praktis

1) Kegiatan Stimulasi Motorik Halus Pada Latihan Kehidupan Praktis

Berdasarkan hasil temuan observasi dan wawancara dengan informan yaitu guru dan kepala sekolah didapatkan informasi bahwa dalam pelaksanaan stimulasi motorik halus sudah sesuai dengan perencanaan. Sedangkan berdasarkan dokumentasi sudah terlihat mengenai pelaksanannya sesuai dengan perencanaan yang telah dibuat.

2) Metode Pelaksanaan Stimulasi Motorik Halus Pada Latihan Kehidupan Praktis

Berdasarkan temuan observasi dan hasil wawancara dengan informan yaitu guru dan kepala sekolah didapatkan informasi bahwa metode yangg digunakan dalam pelaksanaan stimulasi motorik halus pada latihan kehidupan praktis adalah metode tanya jawab, pemberian tugas dan demonstrasi. Sedangkan berdasarkan dokumentasi sudah terlihat mengenai metode yang diguanakan guru setiap kegiatannya.

3) Media Stimulasi Motorik Halus Pada Latihan Kehidupan Praktis Berdasarkan temuan observasi dan hasil wawancara dengan informan yaitu guru dan kepala sekolah didapatkan informasi bahwa media yang digunakan dalam stimulasi motorik halus disesuaikan dengan kegiatan yang akan dilakukan. Misalnya membuat jeruk peras menggunakan media pemeras jeruk dan gelas. Kegiatan planting flower (menanam bunga) menggunakan media pot, sekop kecil, tanah dan plastic golf. Kegiatan making salad fruit 
membuat salad buah) menggunakan buah-buahan, pisau plastik dan telenan. Kegiatan watering flower (menyiram bunga) menggunakan watering can atau penyiram bunga. Kegiatan nut and bolt menggunakan nut and bolt. Sedangkan berdasarkan dokumentasi terlihat guru menggunakan media yang sesuai dengan usia dan kebutuhan anak.

c. Deskripsi Tentang Evaluasi Stimulasi Motorik Halus Pada Latihan Kehidupan Praktis Berdasarkan hasil dokumentasi peneliti didapatkan informasi bahwa evaluasi bahwa evaluasi stimulasi motorik halus pada latihan kehidupan motorik halus pada latihan kehidupan praktis berupa observasi dan tanya jawab. Kemudian guru menggunakan alat penilaian berupa catatan hasil kerja. Dalam proses evaluasi guru juga menggunakan alat penilaian catatan anekdot dan portfolio yang nantinya akan dirangkum pada rubrik untuk laporan semesteran anak.

\section{Penyajian Data}

Dari data yang sudah direduksi, maka dapat disajikan data sebagai berikut:

a. Perencanaan Stimulasi Motorik Halus Pada Latihan Kehidupan Praktis

Perencanaan stimulasi motorik halus pada latihan kehidupan praktis melalui beberapa tahap. Pada awal semester guru merancang
Individual lesson plan dilanjutkan dengan merancang weekly plan, setelah itu, membuat time table. Time table dirancang oleh guru sebelum kegiatan dilaksanakan yaitu seminggu sebelum mulai pembelajaran pada hari Jum'at. Rancangan ini berpedoman pada tema dan tingkat perkembangan masing-masing anak.

\section{b. Pelaksanaan Stimulasi Motorik Halus Pada Latihan Kehidupan Praktis}

1) Kegiatan stimulasi motorik halus pada latihan kehidupan praktik

Kegiatan stimulasi motorik halus pada latihan kehidupan praktis pada TK Pioneer Montessori School Padang sebagian besar sudah sesuai dengan rencana yang telah dirancang pada minggu sebelumnya. Perencanaan ini disesuaikan dengan tema dan tingkat kemampuan anak. kegiatan yang dilaksankan dalam stimulasi motorik halus anak pada latihan kehidupan praktis adalah kegiatan yang menstimulasi otot-otot kecil seperti jari jemari anak melalui kegiatan sehari-hari anak. kegiatan tersebut contonhnya squishing orange (memeras jeruk), planting flower (menanam bunga), watering flower (menyiram bunga), dan nut and bolt (mur dan baut).

2) Metode Stimulasi Motorik Halus Pada Latihan Kehidupan Praktis 
Metode stimulasi motorik halus pada latihan kehidupan praktis di TK Pionerr Montessori School Padang sudah bervariasi dan menarik bagi anak. metode yang dapat digunakan dalam mengembangkan motorik halus anak adalah metode demonstrasi, praktik langsung dan pemberian tugas yang dapat memberikan rangsangan untuk menstimulasi kemampuan otot-otot kecil seperti jari-jemari anak.

\section{3) Media Stimulasi Motorik Pada Latihan Kehidupan Praktis}

Media yang digunakan dalam stimulasi motorik halus pada latihan kehidupan praktis di TK Pioneer Montessori School Padang adalah media yang digagas oleh Montessori berupa bendabenda replika dari benda asli. Media tersebut dapat melatih dan menstimulasi gerak tubuh anak khususnya motorik halus, serta menumbuhkan kemandirian dan kedisiplinan pada anak. Media yang digunakan dalam stimulasi motorik halus anak dapat merangsang otot-otot kecil anak seperti jari-jemari anak.

c. Evaluasi Stimulasi Motorik Halus Pada Latihan Kehidupan Praktis

Cara guru melakukan evaluasi adalah dengan observasi, yaitu dengan melihat proses anak mengerjakan kegiatan stimulasi motorik halus yang diberikan guru.
Guru selanjutnya melihat hasil kerja anak dan menulis dalam catatan anekdot. Evaluasi yang digunakan sebagian besar sesuai dengan yang direncanakan.

\section{Keabsahan Data}

Uji keabsahan data menggunakan triangulasi sumber dan teknik. Triangulasi adalah salah satu teknik dalam pengumpulan data untuk mendapatkan temuan dan interpretasi data agar lebih akurat dan kredibel. Cara yang dapat digunakan yaitu dengan menggunakan sumber yang banyak dan menggunakan metode yang berbeda. Penggunaan sumber yang banyak untuk triangulasi dapat dilakukan dengan mencari sumber yang lebih banyak dan berbeda dalam informasi yang sama.

\section{HASIL DAN PEMBAHASAN}

Sekolah Taman KanakKanak Pioneer Montessori School Padang yang terletak didaerah pondok, kecamatan padang barat adalah salah satu sekolah yang dalam kegiatannya mengenalkan anak tentang latihan kehidupan praktis. Pembelajaran yang dilakukan menggunakan kurikulum nasional dan di padupadankan menggunakan konsep Montessori.

Berdasarkan temuan peneliti di lapangan mengenai pelaksanaan stimulasi motorik halus pada latihan kehidupan praktis di Taman Kanak-Kanak 
Pioneer Montessori School Padang dengan teknik pengambilan data melalui observasi, wawancara dan dokumentasi maka didapatkan hasil sebagai berikut:

\section{A. Perencanaan Stimulasi Motorik Halus Pada Latihan Kehidupan Praktis}

Taman kanak-kanak Pioneer Montessori School Padang sebelum melakukan kegiatan pembelajaran terlebih dahulu membuat perencanaan untuk menstimulasi motorik halus anak. pembuatan perencanaan stimulasi motorik halus memperhatikan tema, sub tema dan perkembangan anak, dan strategi pembelajaran berupa tujuan, materi, media, metode dan evaluasi. Semua komponen tersebut tertulis pada individual lesson plan yang telah dirancang.

Penjelasan di atas mengenai perencanaan kegiatan stimulasi motorik halus pada latihan kehidupan praktis sessuai dengan pendapat yang dikemukakan oleh Sanjaya (2012:28) bahwa perencanaan pembelajaran adalah proses mengambil keputusan hasil berpikir secara rasional tentang sasaran dan tujuan pembelajaran, yakni perubahan perilaku serta rangkaian kegiatan yang harus dilaksanakan sebagai upaya pencapaian tujuan.

B. Pelaksanaan Stimulasi Motorik Halus Pada Latihan Kehidupan Praktis
1) Kegiatan Stimulasi Motorik Halus Pada Latihan Kehidupan Praktis

motorik halus pada latihan
kehidupan praktis juga sudah bervariasi sesuai dengan kegiatan yang ada pada area latihan kehidupan praktis. Kegiatan tersebut meliputi kegiatan yang di dalamnya melibatkan otot-otot jari anak. Menurut Morrison (2012:111) latihan kehidupan praktis adalah lingkungan yang siap menekankan aktivitas motorik dasar sehari-hari. kegiatan yang dilaksanakan pada saat peneliti melakukan kegiatan penelitian diantaranya adalah kegiatan squishing orange (memeras jeruk), making salad fruit (membuat salad buah), planting flower (menanam bunga), watering flower (menyiram bunga), dan nut and bolt (mur dan baut).

$$
\text { Joosten }
$$

menyatakan bahwa tujuan latihan kehidupan praktis adalah latihan aktivitas sehari-hari seperti yang dilakukan orang dewasa seperti menjaga lingkungan.

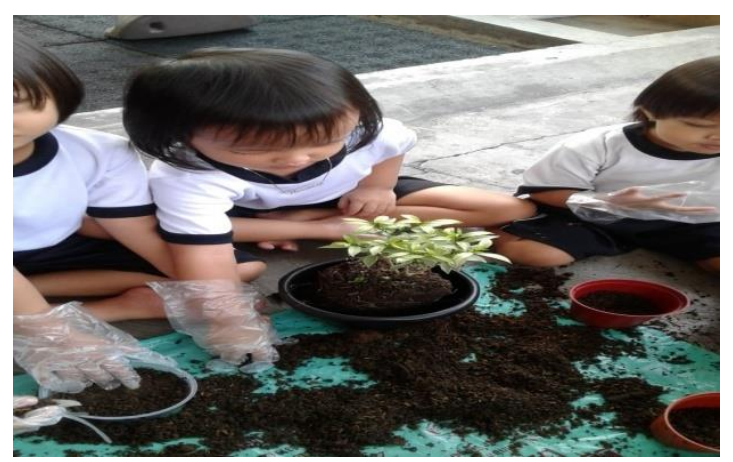


Foto 1. Anak menanam bunga merupakan salah satu

kegiatan pada area latihan kehidupan praktis untuk stimulasi motorik halus anak.

Berdasarkan pembahasan, dapat disimpulkan bahwa pada latihan kehidupan praktis merupakan suatu area yang disiapkan untuk mengembangkan kemampuan motorik dasar, selain itu, terdapat banyak ragam kegiatan yang dapat diterapkan untuk menstimulasi motorik halus anak melalui kegiatan mengenggam, menulis, menggambar, meronce, menjimpit, membalikkan halaman, menempel, menggunting dan menempel.

2) Metode Stimulasi Motorik

Halus Pada Latihan Kehidupan Praktis

Metode demonstrasi adalah metode yang digunakan saat guru mencotohkan bagaimana kegiatan yang akan dilakukan oleh anak. Sedangkan metode pemberian tugas digunakan guru untuk menstimulasi motorik halus dimana anak langsung melakukan kegiatan yang diberikan guru.

Metode demonstrasi yang digunakan untuk kegiatan stimulasi motorik halus ini sesuai dengan pendapat Moeslichatoen (2007:16-17) yang menjelaskan bahwa dalam memberikan stimulasi motorik diperlukan keterampilan mengingat dan mengalami.
Sejalan dengan itu menurut Montessori dalam Britton (2017:13) anak yang masih kecil memiliki pikiran yanng menyerap atau absorbent mind yaitu pikiran yang tidak sadar menyerap informasi dari lingkungan dan mempelajarinya dengan kecepatan tinggi sehingga pengalaman yang diberikan untuk anak akan mudah diingat oleh anak. Pengalaman yang diperoleh anak merupakan hal penting untuk stimulasi motorik halus.

Pada latihan kehidupan praktis Montessori anak akan disuguhkan dengan pengalaman nyata pada kegiatan sehari-hari. Dengan kata lain, anak perlu diberikan latihan-latihan untuk menstimulasi motorik halusnya.

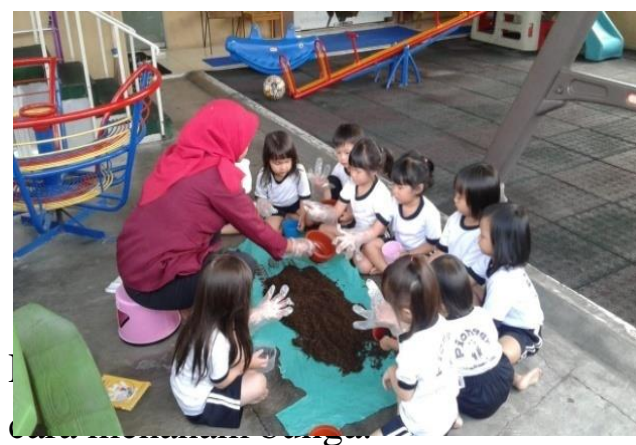

Dengan

kegiatan

demonstrasi, guru dapat meningkatkan pemahaman anak melalui penglihatan dan pendengaran. Anak diminta untuk memperhatikan dan mendengarkan baik-baik semua keterangan guru sehingga ia lebih paham tentang cara mengerjakan sesuatu. Dengan demikian selanjutnya anak dapat meniru bagaimana cara melakukan 
hal tersebut seperti yang dicontohkan guru.

Berdasarkan beberapa

pendapat tersebut, terlihat bahwa metode demonstrasi adalah metode yang sesuai digunakan dalam stimulasi motorik halus Hal ini disebabkan karena dalam metode demonstrasi guru menunjukkan, mengerjakan, dan menjelaskan cara-cara mengerjakan sesuatu dimana anak dapat melihat dan mendengar sehingga anak menjadi lebih paham dan bisa meniru bagaimana cara melakukan kegiatannya, yang kemudian akan memberikan pengalaman belajar kepada anak dalam melatih koordinasi mata dan jari jemarinya.

Selanjutnya metode yang digunakan dalam kegiatan stimulasi motorik halus adalah metode pemberian tugas, hal ini sesuai dengan pendapat Moeslichatoen (2007:28) bahwa metode pemberian tugas merupakan pekerjaan tertentu yang dengan sengaja harus dikerjakan oleh anak yang mendapat tugas. Dengan begitu anak mendapat kesempatan kepada anak untuk mengalami secara langsung serta menyelesaikannya sampai tuntas.

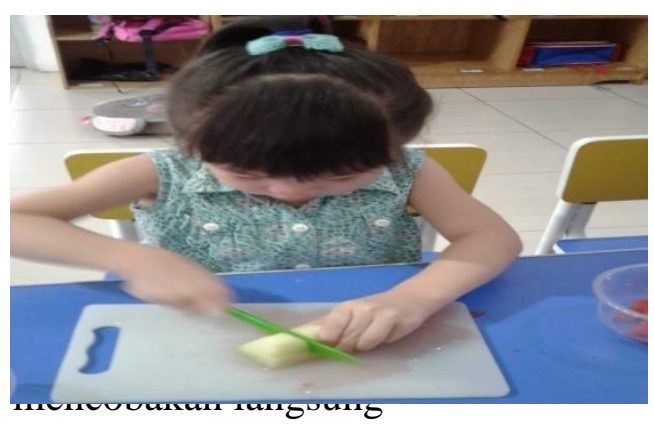

memotong buah sebagai salah satu metode stimulasi motorik halus pada latihan kehidupan praktis.

Oleh karena itu, pemberian tugas adalah salah satu metode yang cocok untuk menstimulasi motorik halus anak. Dalam kaitan keterampilan motorik halus dapat dicontohkan dengan kegiatan seperti squishing orange (memeras jeruk), making salad fruit (membuat salad buah), planting flower (menanam bunga), watering flower (menyiram bunga), dan nut and bolt (mur dan baut).

Berdasarkan pendapat di atas, terlihat bahwa metode pemberian tugas cocok digunakan untuk mengembangkan motorik halus anak usia dini. Hal ini disebabkan karena metode ini memberikan pengalaman belajar untuk anak melalui pelaksanaan tugas secara nyata hingga tuntas.

Dari kedua pembahasan di atas dapat disimpulkan bahwa metode stimulasi motorik halus pada latihan kehidupan praktis ada dua, yakni metode demonstrasi yang berarti guru memberikan contoh dan menjelaskan untuk melakukan suatu kegiatan dengan harapan anak dapat memahami dan menerapkan. Metode yang kedua yaitu metode pemberian tugas dimana dengan metode ini anak diberi kesempatan untuk dapat mengalami dan mengerjakan kegiatan yang telah dijelaskan oleh guru. 
3) Media Stimulasi Motorik Halus Pada Latihan

Kehidupan Praktis

Berdasarkan hasil temuan di lapangan bahwa terdapat beragam media yang digunakan dalam kegiatan stimulasi motorik halus anak usia dini di Taman Kanak-Kanak Pioneer Montessori School Padang. Media atau alat yang digunakan sesuai dengan kegiatan stimulasi yang dilakukan untuk melatih keterampilan gerak tubuh anak khususnya motorik halus, menumbuhkan perasaan senang pada anak, serta memiliki tujuan yang bermakna untuk menyiapkan anak belajar kedepan. Anak diajarkan menggunakan media kongkrit yang bisa mereka amati sendiri dalam penggunaan kehidupan sehari-hari.

Guru memperhatikan media atau alat yang akan diajarkan pada anak bersesuaian dengan apa yang dikemukakan Joosten dalam The NAMTA Journal (2013:8) yang menyatakan bahwa media yang digunakan pada latihan kehidupan praktis adalah media yang memiliki kriteria sebagai berikut: 1) proporsi fisik, 2) pemeliharaan, 3) daya tarik, 4) karakter lokal (adaptasi) , 5) kesempurnaan, 6) diferensiasi, 7) set material independen, 8) multiple set, 9) perlihatkan material di lingkungan, dan 10) pemisahan.Dari pembahasan di atas dapat disimpulkan bahwa media atau alat yang digunakan sesuai dengan prinsip yang dikemukanan oleh
Montessori untuk stimulasi
motorik halus.

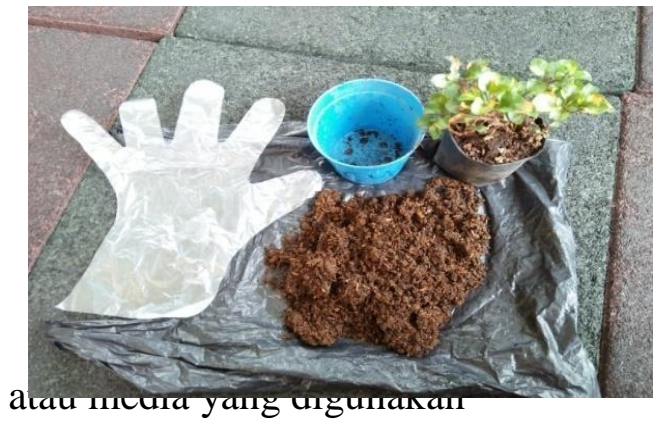

dalam stimulasi motorik halus pada latihan kehidupan praktis.
C. Evaluasi Stimulasi Motorik Halus Pada Latihan Kehidupan Praktis

Berdasarkan hasil temuan penelitian yang peneliti lakukan, guru mengevaluasi stimulasi motorik halus anak dengan cara observasi, yaitu dengan melihat proses anak mengerjakan tugas yang diberikan oleh guru catatan hasil karya, catatan anekdot dan pemberian tanda bintang pada hasil kerja anak. Evaluasi yang dilakukan sebagian besar bersesuaian dengan yang direncanakan. Hal ini sesuai dengan pendapat Latif dkk (2013:88) yang menyatakan bahwa evaluasi dikumpulkan dari hasil kerja anak, dan catatan dari pengamatan guru.

Sesuai dengan pendapat yang di atas Rusman (2012:13) menegaskan bahwa penilaian/evaluasi merupakan suatu tindakan yang dilakukan oleh guru terhadap hasil pembelajaran untuk mengukur tingkat 
pencapaian kompetensi anak dalam bentuk tertulis/lisan, pengamatan kerja, penilaian hasil karya/portofolio serta penilaian diri.

Suryana (2016:339-341)

mengemukakan penilaian anak usia dini seperti berikut: 1) portofolio, yaitu bertujuan untuk mengukur sejauhmana kemampuan peserta didik dalam membangun dan merefleksi suatu pekerjaan/tugas atau karya, 2) catatan anekdot, yaitu Merupakan catatan sikap dan perilaku anak secara khusus terhadap suatu peristiwa yang terjadi pada saat tertentu dan dalam situasi tertentu,

3) hasil karya, Hasil karya adalah hasil kerja anak didik setelah melakukan suatu kegiatan dapat berupa pekerjaan tangan, karya seni atau hasil kegiatan anak lainnya.

Berdasarkan hasil penelitian yang di lakukan di TK Pioneer Montessori School Padang menunjukkan bahwa evaluasi yang dilakukan untuk stimulasi motorik halus sudah sesuai dengan teori evaluasi. Hal ini peneliti lihat dari cara guru menilai perkembangan kemampuan motorik anak dengan beberapa teknik yaitu teknik observasi, pemberian tugas, mengumpulkan portfolio dan catatan anekdot yang sudah sesuai dengan teori yang dikemukakan di atas.

\section{Simpulan dan Saran}

Berdasarkan hasil penelitian yang telah peneliti lakukan tentang stimulasi motorik halus pada latihan kehidupan praktis di Taman Kanak-Kanak Pioneer Montessori School Padang disimpulkan bahwa kegiatan stimulasi yang dilakukan dalam bentuk kegiatan keterampilan hidup sehari-hari telah terlaksana dengan baik. Hal ini terlihat dari perkembangan anak pada aspek motorik halus yang peneliti amati . Anak melakukan beragam kegiatan keterampilan hidup sehari-hari yang melibatkan motorik halus seperti memeras buah jeruk, memotong buah untuk dijadikan salad buah, menanam bunga, menyiram bunga dengan menggunakan penyiram bunga, serta melakukan kegiatan memutar nut and bolt. Kemampuan anak melakukan beragam kegiatan tersebut tidak terlepas dari peran guru yang telah merancang kegiatan, menggunakan metode dan media serta evaluasi yang digunakan.

Pertama, tentang perencanaan kegiatan pengembangan motorik halus anak. Perencanaan yang dibuat oleh guru ada individual lesson plan yang dirancang untuk tiga bulan pembelajaran. Rancangan mingguan dirancang dalam bentuk weekly plan, selanjutnya untuk harian dirancang time table sebagai rancangan kegiatan harian. Yaitu, dirancang seminggu sebelum kegiatan. Rancangan kegiatan ini 
berpedoman pada tema, sub tema dan perkembangan anak.

Kedua, tentang pelaksanaan kegiatan pengembangan motorik halus anak. Kegiatan yang dilaksanakan guru sudah sesuai dengan perencanaan yang dibuat. Metode yang digunakan guru yaitu metode demonstrasi dan metode unjuk kerja Sejalan dengan media yang digunakan guru yaitu media yang disesuaikan dengan kegiatan pengembangan yang dilakukan, dan media yang digunakan dapat melatih keterampilan gerak tubuh anak khususnya motorik halus, serta menumbuhkan perasaan senang pada anak. Guru memperhatikan media yang digunakan anak dari segi keamanan, mudah, menarik dan sesuai dengan usia serta sesuai dengan kegiatan yang akan dilakukan.

Ketiga, tentang evaluasi kegiatan pengembangan motorik halus anak. Guru melakukan evaluasi adalah dengan cara observasi, yaitu dengan melihat proses anak mengerjakan kegiatan yang diberikan guru. Guru menggunakan catatan hasil karya, catatan anekdot, pemberian stiker dan bintang pada hasil kerja anak. Evaluasi yang digunakan sebagian besar sesuai dengan yang direncanakan.

Berdasarkan hasil penelitian tersebut, diharapkan guru dapat memberikan stimulasi motorik halus yang sesuai dengan kegiatan yang ada pada area latihan kehidupan praktis dengan menggunakan prinsip Montessori.

\section{Daftar Rujukan}

Bhatia, Punum, Alan Davis \& Ellen Shamas-Brandt. 2015. Educational Gymnastics: $\quad$ The Effectiveness Of Montessori Practical Life Activities In Developing Fine Motor Skills In Kindergartners. Early Education and Development. DOI: 10.1080/10409289.2015.9 95454.

Britton, Lesley. 2017. Montessori Play and Learn (Terj). Yogyakarta: B First

Joosten. 2013. Exercise of Pratical Life: Introduction and List. The NAMTA Journal. Vol.38, No.2. Spring 2013

Latif, Mukhtar, dkk. 2014. Orientasi Baru

Pendidikan Anak Usia Dini: Teori Dan Aplikasi. Jakarta: Kencana

Ismail, Andang. 2009. Education Games. Yogyakarta: proU Media

Moeslischatoen. 2004. Metode Pengajaran Di Taman Kanak-Kanak. Jakarta: Rineka Cipta

Morrison, George. 2012. DasarDasar Pendidikan Anak Usia Dini (PAUD). Jakarta: PT Indeks.

Mulyasa. 2012. Manajemen PAUD. Bandung: Remaja Rosdakarya.

Sanjaya, Wina. 2006. Strategi Pembelajaran 
Berorientasi Standar

Proses Pendidikan.

Jakarta: Kencana

Santrock, John W. 2007. Masa

Perkembangan Anak.

Jakarta: Selemba

Humanika

Sugiyono. 2008. Metode

Penelitian Pendidikan

Pendekatan Kuantitatif,

Kualitatif, dan $R \& D$.

Bandung: Alfabeta

Suryana, Dadan. 2016. Stimulasi \&

Aspek Perkembangan

Anak. Jakarta: Kencana. 